\title{
RESEARCH IN ENVIRONMENTAL EDUCATION IN THE STATE OF PARAÍBA, BRAZIL: ANALYSIS OF ITS INSERTION AND PROFESSORS' COMMITMENT IN POST-GRADUATE COURSES
}

\author{
Humarah Danielle de Lima Vasconcelos ${ }^{1}$ \\ Edevaldo da Silva ${ }^{2}$
}

\begin{abstract}
Insertion of research on Environmental Education in post-graduate courses in the federal universities of the state of Paraíba, Brazil, is evaluated. Data of professors, dissertations and theses published by post-graduate programs (title, year of completion, author, supervisor) were collected. One hundred and eleven professors involved in teaching and research on environmental issues were identified, coupled to 17 post-graduate programs that produced dissertations and theses related to Environmental Education. Most research concerned soil and agriculture (41.7\%) and water resources $(31.0 \%)$. Professors exhibited a multidisciplinary profile and research focused on the most relevant environmental issues in the region.
\end{abstract}

Keywords: Post-graduate Courses; Interdisciplinarity; Capacity.

Resumo: Esse trabalho objetivou avaliar a inserção da pesquisa relacionada à Educação Ambiental nos cursos de pós-graduações das universidades federais do Estado da Paraíba. Foram coletados dados do perfil dos docentes e das dissertações e teses publicadas pelas pós-graduações (título, ano de defesa, autor, orientador). Entre pesquisa e ensino, foram 111 professores envolvidos com essa área ambiental, sendo identificados 17 programas de pós-graduação que produzem dissertações e teses relacionada com a Educação Ambiental. A maioria das pesquisas foi relacionada ao solo e agricultura $(41,7 \%)$ e aos recursos hídricos $(31,0 \%)$. Os docentes apresentaram perfil multidisciplinar e a pesquisa teve foco para problemas ambientais mais recorrentes para a região.

Palavras-chave: Stricto sensu; Interdisciplinaridade; Capacitação.

\footnotetext{
${ }^{1}$ Universidade Federal de Campina Grande. E-mail: humarah@hotmail.com

2 Universidade Federal de Campina Grande. E-mail: edevaldos@yahoo.com.br
} 


\section{Introduction}

Our era is characterized by a profound awareness of the relationship between nature and human beings, essential for sustainability. In fact, unbridled development in degrading and inadequate practices within the environment contributed towards the current social and environmental imbalance (MARTINS; OLIVEIRA, 2015). Environmental Education originated during a period of social disorder derived from environmental impacts caused by scientific and technological progress and its birth aimed at improving human relationships and conscience-raising for the proper interactions between humans and the environment (CAVALCANTE; COSTA; CHRISPINO, 2014).

Within the context of quality of life, it is mandatory that people should be educated for a more harmonious conviviality with the environment in which they are inserted and from which they make their living. Consequently Environmental Education is not the exclusive issue for environmentalists or experts on the subject matter, but a highly relevant issue for the entire community (SILVA; HAETINGER, 2012).

Social and environmental harmony has been perceived to be basic for the improvement of city life. So that cities and towns may reach economic and environmental equilibrium, the transformation of their knowledge and technological innovations should be conducted in a more sustainable manner (FURLAN; PAIANO, 2011).

In Brazil, the 1999 National Policy for Environmental Education (NPEE) made mandatory the establishment, maintenance and implementation of Environmental Education programs linked to all teaching levels and modes (BRANDALISE et al., 2014). Environmental Education should be inserted in the educational field, especially in universities, due to the constant challenge of knowledge that requires updated formation (BILERT; LINGNAU; OLIVEIRA, 2014). According to Warken et al. (2014), the involvement of Institutions for Higher Education in Environmental Education is highly relevant due to their important role in society. In the struggle for sustainability perhaps no other Institution contributes more than the higher education network.

The University is a relevant place for the building of knowledge and initial formation of educators. Based on teaching, research and updated information, it is a great help to warrant the production of knowledge within and outside its premises (GOMES, 2014).

The insertion of knowledge, criteria and social, ethical and environmental values in university studies and curricula comprises an environmental curriculum for an education in environmental sustainability. Pedagogical projects and teaching planning must contain curricular tools so that the environmental and all its complexity could be understood (GUERRA; FIGUEIREDO, 2014).

Zuin, Farias; Freitas, (2009, p 554) state that: 
The NPEE does not merely consider EE as an essential and permanent item in national education at all educational levels and modes (Art. $2^{\circ}$ ), but gives priority to "the incorporation of the environmental dimension in the formation, specialization and updating" of educators, professors and other professionals of all areas of knowledge so that environmental ethics of the professional activities that would be developed in the exercise of the profession should be inserted in their technical and professional formation (Art. 10, § $3^{\circ}$ ).

According to Pavesi e Freitas (2013), university professors are the basic link within the process of curricular involvement since the later demands the deployment of knowledge which foregrounds their competences.

The scientific method with its predominant model has been necessary for specialized knowledge and technological progress, with the required insertion of the issue of sustainable development in academic curricula of universities, especially in Post-graduate programs (RABELO et al., 2013).

Rabelo (2013, p.639) insists that:

Science and technology should be highlighted. Whereas science provides means for the understanding of the universe and the limitations of humans on the planet, technology provides the tools for changes, including paradigms. These ideas should be applied in post-graduate courses, [...] which were planned to train people for decision-taking.

Investigation is one of the most important criteria employed in universities. It produces new knowledge and, as a rule, solves the communities' complex problems. Projects and activities of environmental formation become a priority within such a context (NIÑO; ROMERO, 2014).

In their role as investigation and learning centers, Universities are a locus for debates, discussions and research on Environmental Education and provide the community with new possibilities that insert knowledge and environmental care within the context of technological, scientific and social progress (MIRIAM, 2003). Therefore, Environmental Education is an essential factor for sustainable development with enormous popularity worldwide. In fact, its influence on the formulation of policies is widely known in several countries (BARBIERI; SILVA, 2011).

Current paper shows the importance of the insertion of Environmental Education in higher education, particularly in post-graduate courses since teaching and learning are the best method for good relationships between humans and nature. 


\section{Metodology}

\section{Population and Sample}

Current descriptive and quantitative research works on data of postgraduate programs, university professors and academic productions (theses and dissertations) of government-run federal universities of the state of Paraíba, Brazil, within an area related to Environmental Education. Data retrieved from post-graduate programs of the Federal University of Campina Grande (UFCG), Federal University of Paraíba (UFPB) and the State University of Paraíba (UEPB) were analyzed.

Prior to data collection and as an exclusion criterion, a survey was undertaken on all post-graduate courses in the above-mentioned institutions to select which courses would be researched. Selection involved all courses characterized directly or indirectly by the following criteria: (1) subject-matters related to Environmental Education and (2) research or concentration related to Environmental Education. Investigation was also focused, within these criteria, to see whether the discipline or research highlighted the key terms preservation, conservation, degradation, contamination, pollution, management and administration.

\section{Collection and Data Analysis}

Data collected belonged to public domain and were available online in the Lattes search engines and sites of the respective post-graduate programs of the institutions. Technical visits were undertaken to the offices of the postgraduate courses and to the university libraries when data on the electronic sites proved to be insufficient. The following data were harvested: Data on professors: gender, degrees (Undergraduate, Master and Doctorate) and year of completion, and (2) data on academic production (theses and dissertations) with title, year of completion, author, supervisor.

Data were analyzed to identify the profile of professors involved in Environmental Education and verify trends in the publications with regard to the specific theme underscored. Theses and dissertations were grouped under the following environmental headings: climatic changes, fauna, vegetal resources, mineral resources, solid wastes, water resources, soil and agriculture.

\section{Results}

One hundred and eleven professors, $63.1 \%$ males and 36.9 females, worked or gave lectures on disciplines underscoring environment. Their predominant academic undergraduate formation comprised Biological Sciences (34.0\%), Agronomy (10.0\%) and Chemistry/Industrial Chemistry (10.0\%; Table 1). The four undergraduate courses above were the formation milieu of $54.0 \%$ of the teaching boards involved in post-graduate courses and in the 
environmental area. On the other hand, the other $46.0 \%$ of professors were distributed in several courses of different areas of knowledge, such as Natural Science, Humanities and Exact Sciences. They graduated between 1970 and 1989, most of whom obtained their Master's degree between 1990 and 1999, and their doctorate between 2000 and 2012 (Figure 1).

Table 1: Frequency (fa) in professional formation (undergraduate) of professors involved in Environmental Education in post-graduate courses of the federal universities in the state of Paraíba, Brazil $(N=111)$.

\begin{tabular}{l|c||l|c}
\hline \multicolumn{1}{c|}{ Graduation } & fa & \multicolumn{1}{|c|}{ Graduation } & fa \\
\hline Biological Sciences & 34 & Meteorology & 5 \\
\hline Agronomy & 10 & Architecture And Urbanism & 4 \\
\hline Chemistry / Chemical Industries & 10 & Chemical Engineering & 4 \\
\hline Science / Social Communication & 9 & Agricultural Engineering & 3 \\
\hline Geography & 8 & Civil Engineer & 3 \\
\hline Law & 7 & Other & 22 \\
\hline
\end{tabular}

Table 2 lists post-graduate programs with courses featuring academic production (dissertations and theses) or merely courses with disciplines on the Environment.

Twenty-two courses were identified involved in Environmental Education at all levels (Master's and Doctoral degrees) where $77.3 \%(n=17)$ published dissertations or theses, and $22.7 \%(n=4)$ lectured on subject matters with a focus on the Environment and its issues. It should be underscored that the three federal universities in the state of Paraíba, Brazil, administer postgraduate courses with a focus on the Environment. However, UFCG and UFPB provides the best opportunities.

Several post-graduate courses are available in the humanities and in natural, social and exact sciences, such as Ecology and Conservation, Chemical Engineering, Regional Development, Social Sciences, Law, Forest Sciences, Geography and others, with scientific productions on Environmental Education. 


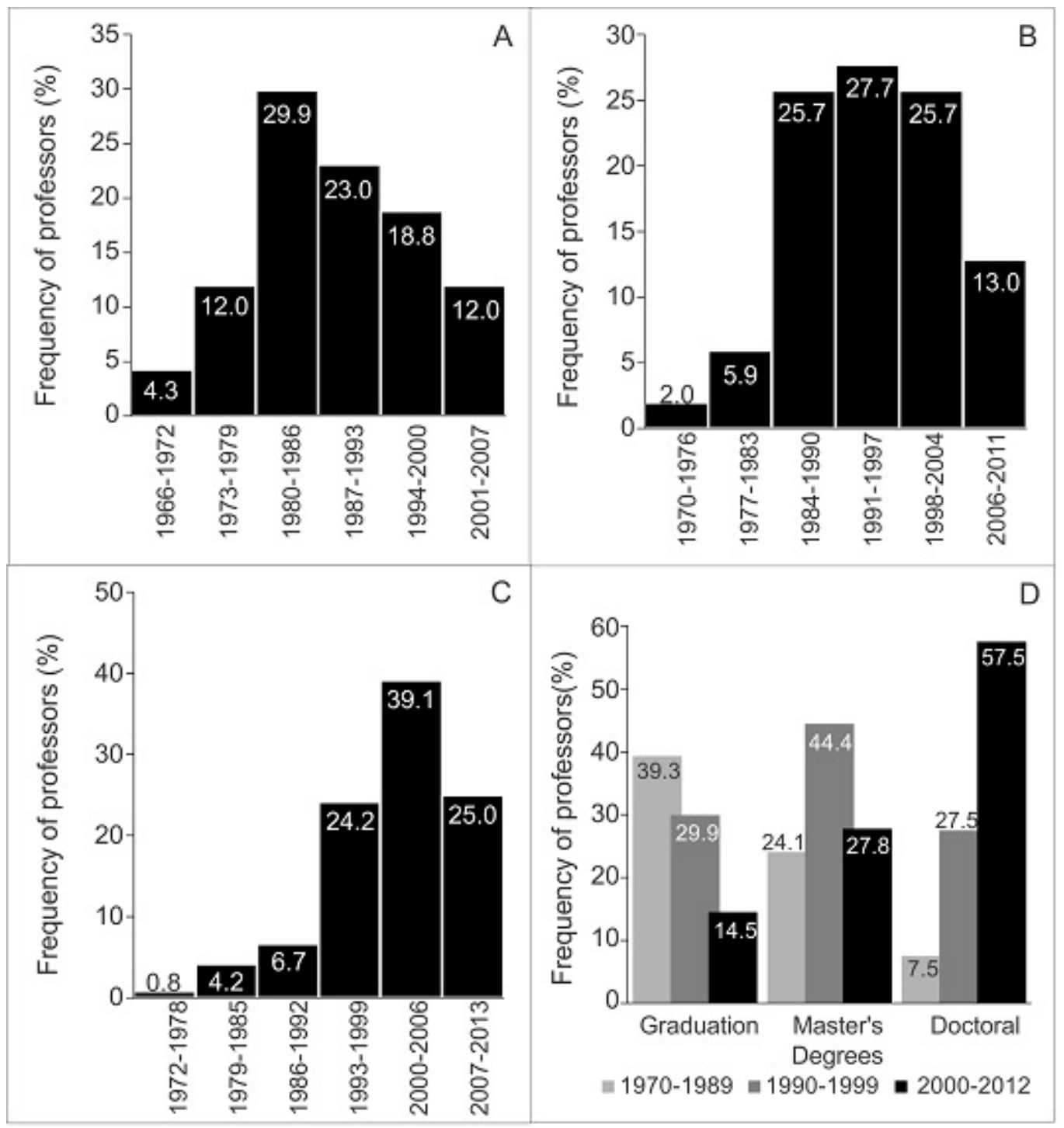

Figure 1: Histogram on the distribution of academic degrees (1A - Undergraduate; $1 \mathrm{~B}-$ Master's; 1C - Doctoral; 1D - general summary of all degrees) of post-graduate professors involved in Environmental Education.

Taking into consideration the predominant environmental themes, the analysis of published dissertations and theses in the several Master's and Doctorate courses in the three federal universities of the state of Paraíba, Brazil, during the last ten years (2005-2014) demonstrated possible trends in research works developed in the region (Figure 2).

Research tended to concentrate on soil and agriculture $(41.7 \%)$ and water resources (31.0\%). In fact, the two themes comprise $71.7 \%$ of scientific investigations on the region's environment problems. On the other hand, research on climate changes (2.4\%) and fauna (3.6\%) are still scarce. 
Table 2: List of post-graduate programs in the federal universities of the state of Paraíba, Brazil, with published dissertations and theses or disciplines related to Environmental Education (EE).

\begin{tabular}{|c|c|c|c|c|c|}
\hline $\begin{array}{l}\text { Post-Graduate Programs } \\
\text { with production related to EE }\end{array}$ & IHE & $\mathbf{L}$ & $\begin{array}{l}\text { Post-Graduate Programs } \\
\text { with production related to EE }\end{array}$ & IHE & $\mathbf{L}$ \\
\hline Social Sciences & UFCG & $\mathrm{M} / \mathrm{D}$ & Chemical Engineering & UFCG & $\mathrm{M} / \mathrm{D}$ \\
\hline Forest Science & UFCG & M & Natural Resources & UFCG & $M / D$ \\
\hline Agribusiness Systems & UFCG & M & Process Engineering & UFCG & $\mathrm{D}$ \\
\hline Geography & UFPB & $M / D$ & Juridical Sciences & UFPB & $M / D$ \\
\hline Agronomy & UFPB & $M / D$ & Biological Sciences & UFPB & $M / D$ \\
\hline Anthropology & UFPB & M & Biotechnology RENORBIO & UFPB & $\mathrm{D}$ \\
\hline $\begin{array}{l}\text { Development and Environment } \\
\text { (PRODEMA) }\end{array}$ & UFPB & $M / D$ & $\begin{array}{l}\text { Science and Environmental } \\
\text { Technology }\end{array}$ & UEPB & $M / D$ \\
\hline Agricultural Sciences & UEPB & M & Regional Development & UEPB & $M$ \\
\hline Ecology and Conservation & UEPB & M & & & \\
\hline $\begin{array}{l}\text { Post-Graduate Programs } \\
\text { with training related to EE }\end{array}$ & IHE & $\mathbf{L}$ & $\begin{array}{l}\text { Post-Graduate Programs } \\
\text { with training related to EE }\end{array}$ & IHE & $\mathbf{L}$ \\
\hline Geography & UFPB & $\mathrm{M} / \mathrm{D}$ & Chemistry & UFPB & $\mathrm{M} / \mathrm{D}$ \\
\hline Meteorology & UFCG & D & Soil Sciences & UFPB & $M / D$ \\
\hline Architecture and Urbanism & UFPB & $M / D$ & & & \\
\hline
\end{tabular}

IHE: Institutes for Higher Education. L: Level. Degrees: M - Master's; D - Doctoral.

Further, the number of professors involved with research or development of environmental disciplines constitutes only a small portion of professors teaching in post-graduate courses under analysis (Figure 3). The greatest number of professors with scientific productions in Environment Education or related subjects is extant only in two post-graduate programs, namely, Postgraduate Program in Development and Environment (PRODEMA) of the UFPB and Post-graduate Program in Natural Resources of the UFCG.

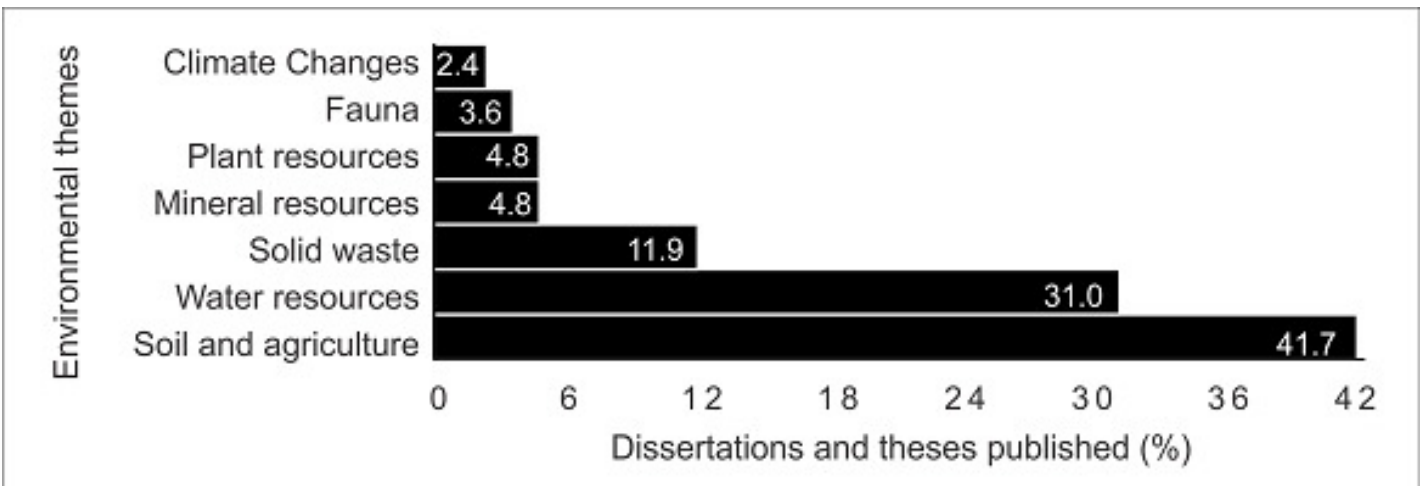

Figure 2: Frequency analysis (\%) of production (dissertations and theses) of post-graduate courses according to their environmental themes $(N=84)$. 


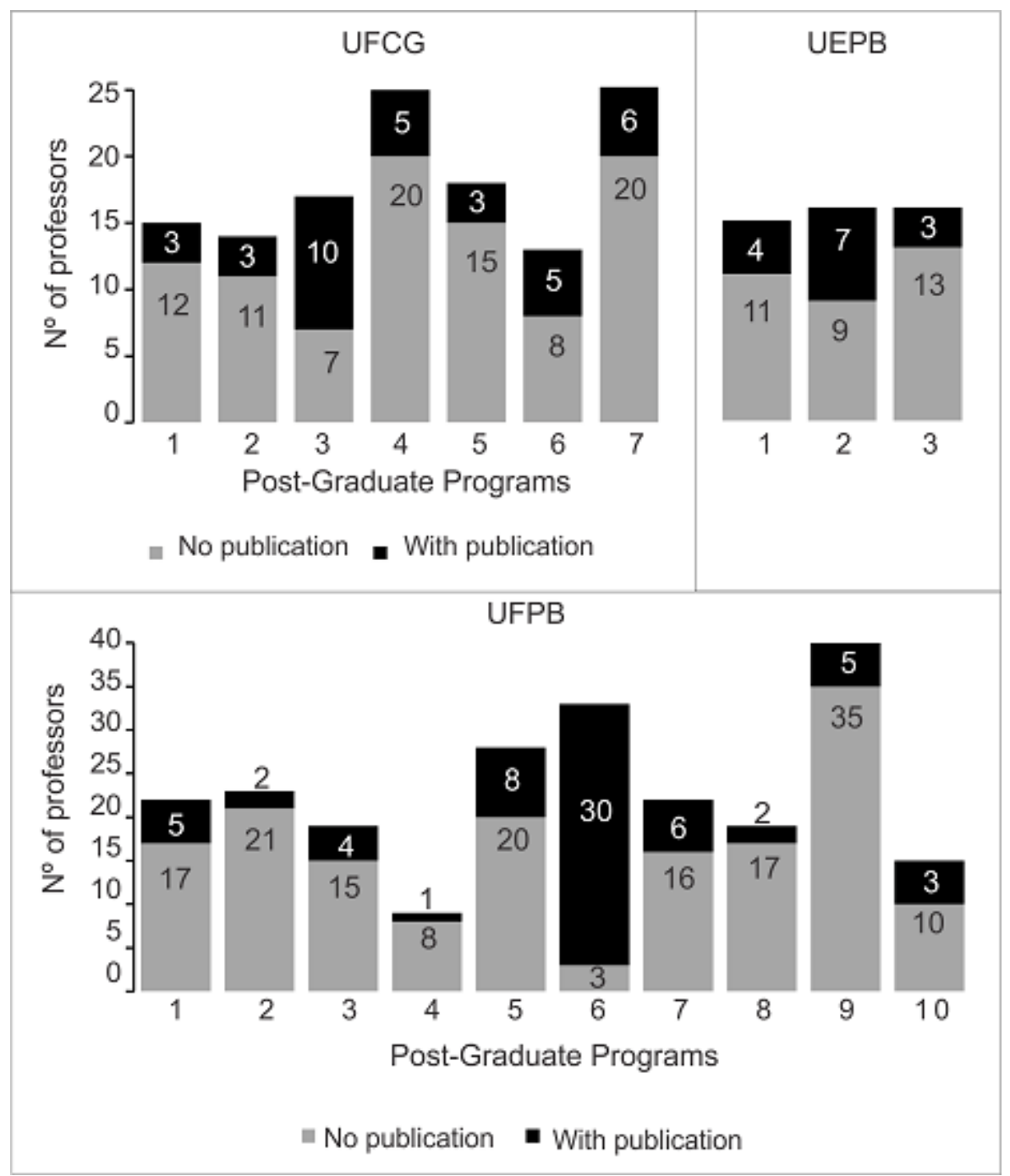

Figure 3: Number of professor in post-graduate courses of the federal universities of the state of Paraíba, Brazil, with or without participation (publication of theses and dissertations) related to Environmental Education between 2005 and 2014.

\section{Discussion}

Although environmental themes in Brazilian scientific productions are highly varied, several research works reveal a predominance of the natureculture theme (REIGOTA, 2007). Moreover, several Institutes for Higher Education (IHE), research centers or non-government organizations have undertaken research on the environment (FRANCALAZA, et. al., 2008). Through their post-graduate program, IHEs provide courses which are directly or indirectly related to the environment and thus enhance research in the area with several scientific productions that are required by post-graduate courses (CARVALHO; FEITOSA, 2011).

\section{According to Larocca; Rosso; Souza (2005, p. 119):}


Within the post-graduate context, concern on the assessment and the dissemination of academic production is certainly foregrounded on the acknowledgement that research must produce reliable and worthy products which, directly and indirectly, contribute towards the improvement of individual and collective life styles.

The government-run federal universities of the state of Paraíba, Brazil, have provided during the past ten years (2005-2014) seventeen post-graduate courses, most of which with a Master's or Doctoral degree in environmental studies. These activities underscore a solid capacity for students and strengthen the network of environmental multipliers capable of developing activities in the region.

According to Reigota (2007), Environmental Education has been the theme in dissertations and theses since 1984 and its institutionalization in several post-graduate programs started from the mid-1990s. The fact that most professors working in post-graduate courses in the federal universities of the state of Paraíba, Brazil, received their Master's and Doctoral degrees in the 1990s may have favored their involvement with Environmental Education. During this period, they experienced an educational stance with the introduction of Environmental Education in Brazilian higher education and thus in postgraduate courses.

Besides research work and the development of knowledge, postgraduate courses contribute towards the formation of environmental educators and the development of curricula and management of the Brazilian educational system. Scientifically or intuitively, environmental educators practice educational activities from several approaches. In fact, several authors describe and classify several trends in the environmental education field (VALENTIN et al., 2012) which is closely related to the interdisciplinary characteristics that such education requires.

The interdisciplinary trend has also been reported among the professors involved in environmental themes in post-graduate programs in Paraíba. This fact demonstrates a diversified academic formation. Although more than half of them graduated in Biological Sciences and Agronomy, they are also distributed among the personnel of the Humanities and the Natural and Exact Sciences.

According to Marques et al. (2014, p 14):

Environmental Education has interdisciplinary features, with an integrated and continuous approach. It has been an important factor to discuss theories and practices that foreground educational activities in formal and informal contexts, for the solution of issues on local conditions, followed by more extensive issues. 
Moreover, Environmental Education enhances ethical values. It is highly relevant that educational space is not a conservational stance but directed towards a change of values with a new world view, involving Environmental Education within an interdisciplinary and transdisciplinary context. Thus Environmental Education comprises a knowledge socially constituted and foregrounded on an inter- and trans-disciplinary language through new values, habits, behaviors and activities related to the environment (MORADILLO; OKI, 2004). Therefore, it involves different types of knowledge and world views and provides the student an integrated, reflexive and critical stance on environmental problems in the region and on the planet.

Trends in academic productions at Master's and Doctoral levels in Paraíba represent the emergent and primordial needs during the ten-year period under analysis, or rather, the environmental issues related to water resources, soil and agriculture. Consequently, research developed in these postgraduate courses significantly is a great help in the technical and scientific knowledge for the benefit of the region, besides capacitating students to investigate environmental resources with a keen environmental perception with regard to limits, degradation and requirements for a more harmonious relationship between humans and the environment.

Guerra; Guimarães (2007, p. 159) insist that:

When the subject is teachers' formation, focus is directed on the formation process in the development of knowledge, capacities and competence. In the case of Environmental Education, emphasis should also be given to the development of values and praxis, with efficacious activities for the insertion of environmental stance in primary and secondary school and university curricula as one of the factors in the educational process.

Education for the construction of citizenship motivates and sensitizes everybody. It transforms all types of participation in a defense for a quality life style. The educator, therefore, has a mediating task within the construction of environmental references and should use them for the development of social practices (JACOBI, 2003).

Research in Environmental Education in post-graduate programs will provide a critical perspective to educators in proportion to their reflexive stance. They should view it as a political-pedagogical practice by motivating and sensitizing the several types of participation in factors capable of widening social and environmental responsibilities.

The number of professors in post-graduation courses committed to Environmental Education demonstrates that only a few are actually involved. However, the transdisciplinary condition of Environmental Education would 
favor a larger number of professors to commit themselves with the research. Such an approach will not necessarily disqualify or modify research but will give further relevance to the environmental dimension and will contribute towards the formation of more qualified students to work within the environmental area. As researchers either in their teaching activities or as mediating citizens, the future professionals will perceive and include it within a transdisciplinary aspect.

Environmental Education is an educational activity that articulates political, social, economic and environmental aspects, coupled to the inclusion of the environmental theme in teachers' formation. In fact, it is a requirement of great important (OLIVEIRA; CARVALHO, 2012). Piato et al. (2014, p. 43) underscore that:

Education for sustainability within higher education may not be considered as a process of curriculum change but as a reassessment of the environmental issues focusing on the university, involving professors, students, technical and administration personnel, managers, disciples, departments, courses, curricular contents, research and updating projects and the entire community in which the university is inserted.

Consequently, the post-graduate courses in which most researchers are involved with research related somewhat with Environmental Education would provide to their students more opportunities for research and experience in this area of knowledge.

\section{Conclusions}

Research related to Environmental Education has already been inserted in several postgraduate courses in the federal universities of the state of Paraíba, Brazil. The most recurring themes, object of current discussion, focus on soil and agriculture and on water resources.

The profile of professors involved in the environmental theme at the teaching level (disciplines) or in the production of dissertations and theses, is very different with regard to undergraduate formation. However, most are biologists, agronomists and chemists.

The diversity in post-graduate courses focused on Environmental Education at all levels and the multidisciplinary profile of the professor provide great opportunities for students' formation with interdisciplinary and variegated points of view within the region. 


\section{References}

BARBIERI, J.C.; SILVA, D. Desenvolvimento sustentável e educação ambiental: uma trajetória comum com muitos desafios. Revista de Administração Mackenzie, v. 12, n. 3, p. 52-82, 2011.

BILERT, V.S.S.; LINGNAU, R.; OLIVEIRA, M.R. A educação ambiental nas universidades públicas estaduais do Paraná: uma análise a partir dos documentos institucionais. Revistas Monográficas Ambientais, v. 13, n. 4, p. 3444-3452, 2014.

BRANDALISE, L.T. et al. A percepção e o comportamento ambiental dos universitários em relação ao grau de educação ambiental. Gestão \& Produção, v. 16, n. 2, p. 273-285.

CARVALHO, D.B.; FEITOSA, C.M.M. A produção brasileira de teses sobre educação ambiental na biblioteca digital brasileira de teses e dissertações (bdtd): uma Análise temática. Ambiente e Educação, v. 16, n. 1, p. 45-57, 2011.

CAVALCANTE, D.B.; COSTA, M.A.T.; CHRISPINO, A. Educação Ambiental e movimento CTS, caminhos para a contextualização do ensino de biologia. Revista Práxis, v. 6, n. 12, 2014.

FRANCALANZA, $\mathrm{H}$. et al. A educação ambiental no Brasil, panorama inicial da produção acadêmica. Ciências em Foco, Bauru - SP, v. 1, n. 1, 2008.

FURLAN, A.C.; PAIANO, D.B. A educação ambiental no ensino superior/ environmental education in higher education. Hiléia: Revista do Direito Ambiental da Amazônia, n. 17, p. 9-25, 2011.

GOMES, M.F.V.B. Formação continuada de professores: reflexões a partir de experiências em projetos de educação ambiental. Currículo sem Fronteiras, v. 14, n. 1, p. 62-75, 2014.

GUERRA, A.F.S.; FIGUEIREDO, M.L. Ambientalização curricular na educação superior: desafios e perspectivas. Educar em Revista, Curitiba, n. 3, p. 109-126, 2014.

GUERRA, A.F.; GUIMARÃES, M. Educação ambiental no contexto escolar: questões levantadas no GDP. Pesquisa em Educação Ambiental, v. 2, n. 1, p. 155-166, 2007.

JACOBI, P.R. Educação Ambiental, cidadania e sustentabilidade. Cadernos de Pesquisa, n. 118, p. 189-205, 2003.

LAROCCA, P.; ROSSO, A. J.; SOUZA, A.P. A formulação dos objetivos de pesquisa na pós-graduação em educação: uma discussão necessária. Revista Brasileira de Pós-Graduação, v. 2, n. 3, p. 118-133, 2005.

LORENZETTI, L.; DELIZOICOV, D. Educação ambiental: um olhar sobre dissertações e teses. Revista Brasileira de Pesquisa em Educação em Ciências, v. 6, n. 2, 2006.

MARQUES, M.L.A.P. et al. A educação ambiental na formação da consciência ecológica. Caderno de Graduação, Ciências Exatas e Tecnológicas, Maceió, v. 1, n. 1, p. 11-18, 2014. 
MARTINS, C.; OLIVEIRA, H.T. Biodiversidade no contexto escolar: concepções e práticas em uma perspectiva de educação ambiental crítica. Revista Brasileira de Educação Ambiental, v. 10, n. 1, p. 127-145, 2015.

MIRIAM, A.C. Medio ambiente y universidad: retos y desafíos ambientales en la universidad autónoma metropolitana-azcapotzalco. El Cotidiano, v. 19, n. 122, p. 86-92, 2003.

MORADILLO, E.F.; OKI, M.C.M. Educação ambiental na universidade; construindo possibilidades. Química Nova, v. 27, n. 2, p. 332-336, 3004.

NIÑO, A.C.M.; ROMERO, J.F.H. La formación ambiental en la educación superior: una revisión necessária. Revista Luna Azúl, n. 39, p. 186-202, 2014.

OLIVEIRA, M.G.; CARVALHO, L.M. Políticas públicas de formação de professores e de educação ambiental: possíveis articulações?. Revista Contemporânea de Educação, v. 7, n. 14, p. 252-275, 2012.

PAVESI, A.; FREITAS, D. Desafios para a ambientalização curricular no ensino superior brasileiro. Anais do IX congreso internacional sobre investigación en didáctica de las ciências. p. 2678- 2682, 2013.

PIATO, R.S. et al. Educação para o desenvolvimento sustentável: o papel da universidade. Archives of Health Investigation, v. 3, n. 6, p. 41-45, 2014.

RABELO, L.S. et al. A experiência do Prodema na pós-graduação brasileira: ciência para a sustentabilidade na UFC. Revista Brasileira de Pós-Graduação, Brasília, v. 10, n. 21, p. 633-660, 2013.

REIGOTA, M. O estado da arte da pesquisa em educação ambiental no Brasil. Pesquisa em Educação Ambiental, v. 2, n. 1, p. 33-66, 2007.

SILVA, A.; HAETINGER, C. Educação ambiental no ensino superior - o conhecimento a favor da qualidade de vida e da conscientização socioambiental. Revista Contexto e Saúde, v. 12, n. 23, p. 34-40, 2012.

SILVA, E. C. R.; FONSECA, A. B. Hortas em escolas urbanas, complexidade e transdisciplinaridade: construção para a educação ambiental e para a educação em saúde. Revista Brasileira de Pesquisa em Educação em Ciências, v. 11, n. 3, p. 35-53, 2011.

VALENTIN, M.W. et al. Educação ambiental em unidades de conservação: políticas públicas e a prática educativa. Educação em Revista, Belo Horizonte, v. 20, n. 1, p. 267-288, 2012.

WARKEN, I.L.M.; HENN, V.J.; ROSA, F.S. Gestão da sustentabilidade: um estudo sobre o nível de sustentabilidade socioambiental de uma instituição federal de ensino superior. Revista de Gestão, Finanças e Contabilidade, Salvador, v. 4, n. 3, p. 147-166, 2014.

ZUIN, V.G.; FARIAS, C.R.; FREITAS, D. A ambientalização curricular na formação inicial de professores de química: considerações sobre uma experiência brasileira. Revista Electrónica de Enseñanza de las Ciencias, v. 8, n. 2, p. 552-570, 2009. 